\title{
Pengaruh Infeksi Cacing Usus yang Ditularkan Melalui Tanah pada Pertumbuhan Fisik Anak Usia Sekolah Dasar
}

\author{
Charles D Siregar
}

\begin{abstract}
Infeksi cacing usus yang ditularkan melalui tanah (soil transmitted helminthiasis) merupakan masalah dunia terutama di negara yang sedang berkembang. Diperkirakan 1 milyar penduduk dunia menderita infeksi parasit cacing. Prevalensi pada anak usia sekolah dasar di Indonesia antara 60\%-80\%. Paling sering disebabkan oleh Ascaris lumbricoides, Trichuris trichiura dan cacing tambang. Infeksi cacing selain berpengaruh terhadap pemasukan, pencernaan, penyerapan, serta metabolisme makanan, yang dapat berakibat hilangnya protein, karbohidrat, lemak, vitamin dan darah dalam jumlah yang besar, juga menimbulkan gangguan respon imun, menurunnya plasma insulin like growth factor (IGF)-1, meningkatkan kadar serum tumor necrosis factor a (TNF), dan menurunkan konsentrasi hemoglobin rerata. Di samping itu dapat menimbulkan berbagai gejala penyakit seperti anemi, diare, sindrom disentri dan defisiensi besi, sehingga anak yang menderita infeksi cacing usus merupakan kelompok risiko tinggi untuk mengalami malnutrisi. Keadaan ini secara tidak langsung dapat menyebabkan gangguan pertumbuhan.
\end{abstract}

Kata kunci: pertumbuhan fisik, Ascaris lumbricoides, Trichuris trichiura, cacing tambang, sekolah dasar

(1) nyakit infeksi cacing usus yang ditularkan melalui tanah (soil transmitted helminthiasis) masih merupakan masalah dunia terutama di negara yang sedang berkembang. ${ }^{1}$ Prevalensi pada anak balita dan murid sekolah dasar tinggi. ${ }^{2}$ World health organization memperkirakan hampir 1 milyar penduduk dunia menderita infeksi parasit cacing. Di Indonesia infeksi cacing usus masih merupakan

Alamat korespondensi:

Dr. Charles D Siregar. Bagian Ilmu Kesehatan Anak Fakultas Kedokteran Universitas Sumatera Utara/ RSUP H.Adam Malik Jl. Bunga Lau no.17 Medan. Tel (061) 8361721 - 8365663 Fax. (061) 8361721 E-mail : bikafkusu@telkom.net; kotak Pos 697 Medan - 20136. problem kesehatan masyarakat yang penting, dengan prevalensi yang cukup tinggi. ${ }^{3}$ Hasil survei di beberapa tempat menunjukkan prevalensi antara 60\%-90\% pada anak usia sekolah dasar. ${ }^{4}$

Empat spesies utama cacing usus yang merupakan persoalan kesehatan masyarakat di Indonesia adalah Ascaris lumbricoides, Trichuris trichiura, Necator americanus dan Ancylostoma duodenale. ${ }^{5}$ Injeksi cacing pada seorang anak dapat ditemukan secara tunggal maupun campuran, ${ }^{1,3,5}$ dan dapat menyebabkan malnutrisi, anemia, menurunnya kesehatan jasmani dan menurunkan selera makan sehingga dapat menyebabkan gangguan pertumbuhan, ${ }^{1-4,6,7}$ dan dapat menyebabkan penurunan kemampuan kognitif. ${ }^{8}$ 
Sari Pediatri, Vol. 8, No. 2, September 2006

\section{Pertumbuhan fisik dan perkembangan anak}

Proses pertumbuhan dapat diketahui dengan mengamati perubahan pada besar dan bentuk yang dinyatakan dalam nilai nilai ukuran tubuh seperti berat badan, tinggi badan, lingkar lengan atas, lingkar kepala dan sebagainya. Dapat diukur dengan ukuran berat (gram, kilogram), ukuran panjang (centimeter, meter) umur tulang dan keseimbangan metabolik (retensi Kalsium dan Nitrogen tubuh). ${ }^{9,10}$

Untuk mencapai pertumbuhan dan perkembangan optimal sesuai dengan potensi genetiknya, seorang anak membutuhkan faktor lingkungan biofisikopsikososial yang adekwat. ${ }^{9} 10$ Faktor lingkungan yang penting diantaranya adalah pengaruh gizi dan penyakit. Penyakit yang diderita anak terutama infeksi akan mengakibatkan kurangnya masukan makanan serta kurangnya kemampuan anak untuk menerima makanan, sementara kebutuhan tubuh semakin meningkat. Keadaan ini akan mengakibatkan gangguan pertumbuhan, yang dapat dilihat dari pertumbuhan linear yang mengurang atau terhenti, kenaikan berat badan yang berkurang, ukuran lingkaran lengan atas dan tebal lipatan kulit yang menurun. ${ }^{10}$

Anak usia sekolah dasar (6-12 tahun) untuk dapat tumbuh membutuhkan kalori dan protein. Pada periode ini berat badan anak meningkat rata rata 3 $3,5 \mathrm{~kg}$ dan tinggi badan kira kira $6 \mathrm{~cm}$ pertahun. ${ }^{11}$ Untuk dapat menjamin pertumbuhan anak dibutuhkan kalori sebesar 1900 - $2000 \mathrm{Kkal}$. dan protein 37 45 gram per hari. Jadi pada masa pertumbuhan seorang anak membutuhkan zat gizi dalam jumlah relatif besar, sehingga suatu kondisi defisiensi akan segera berpengaruh terhadap pertumbuhannya. ${ }^{12,13}$

\section{Pengaruh infeksi Ascaris lumbricoides}

Cacing Ascaris lumbricoides dewasa berbentuk bulat dan besar, panjangnya dapat mencapai $15-30 \mathrm{~cm} \cdot{ }^{14}$ Sehingga akan menempati ruang yang luas dalam rongga usus. Anak yang mengandung cacing gelang dengan jumlah 300 ekor tidak akan merasa lapar; keadaan ini tentunya akan mengurangi masukan makanan bagi anak. ${ }^{3}$ Jumlah cacing yang banyak sangat berhubungan dengan terjadinya malnutrisi, defisit pertumbuhan dan gangguan kebugaran fisik, disamping itu massa cacing itu sendiri dapat menyebabkan obstruksi. ${ }^{1}$ Cacing ini dapat hidup dalam tubuh pasien selama 12-18 bulan. ${ }^{3,5,14}$ Hidup dalam rongga usus halus manusia mengambil makanan terutama karbohidrat dan protein, seekor cacing akan mengambil karbohidrat 0.14 gram per hari dan protein 0.035 gram per hari. ${ }^{6}$ Sel mukosa usus halus (enterosit) mempunyai brush border yang terdiri dari mikrovili. Didalam mikrovili ini terdapat berbagai macam enzim pencernaan. ${ }^{15}$ Adanya Ascaris lumbricoides dalam usus halus dapat menyebabkan kelainan mukosa usus, berupa proses peradangan pada dinding usus, pelebaran dan memendeknya villi, bertambah panjangnya kripta, menurunnya rasio villus kripta dan infiltrasi sel bulat ke lamina propria, yang berakibat pada gangguan absorpsi makanan. Sebagian kelainan ini dapat kembali normal bila cacing dikeluarkan. ${ }^{16,17}$ Efek langsung yang terukur akibat kelainan mukosa usus halus ialah meningkatnya nitrogen dalam tinja, steatorhea karena terjadi gangguan absorpsi lemak, gangguan absorbsi karbohidrat yang diukur dengan $x y$ lose test ${ }^{14}$ Akibat lainnya adalah cacing ini menyebabkan hiperperistaltik sehingga menimbulkan diare, juga dapat mengakibatkan rasa tidak enak diperut, kolik akut pada daerah epigastrium dan gangguan selera makan. Keadaan ini terjadi pada saat proses peradangan pada dinding usus. ${ }^{17-19}$

Gangguan absorpsi vitamin A dapat terjadi pada anak yang menderita askariasis. ${ }^{14}$ Kekurangan vitamin A dapat menghambat pertumbuhan sel, termasuk sel tulang, dan dapat mengganggu sel yang membentuk email serta dentin pada gigi. ${ }^{13}$ Namun sampai dimana vitamin A digunakan dan dihancurkan oleh cacing masih belum jelas, namun dampak klinis defisiensi vitamin tersebut pada penderita askariasis dapat lebih berat. Juga didapati bukti penting mengenai efek terbalik askariasis terhadap vitamin $\mathrm{C}$ dalam plasma dan sekresi riboflavin dalam air seni. ${ }^{8}$

\section{Pengaruh infeksi Trichuris trichiura}

Trichuris trichiura atau cacing cambuk merupakan salah satu Nematoda usus yang penting pada manusia, cacing ini hidup di daerah sekum..$^{20,21}$ Mekanisme pasti bagaimana cacing ini menimbulkan kelainan pada manusia tidak diketahui, akan tetapi diketahui ada dua proses yang berperan, yaitu trauma oleh 
Sari Pediatri, Vol. 8, No. 2, September 2006

cacing dan efek toksik. ${ }^{14}$ Trauma pada dinding usus terjadi karena cacing ini membenamkan bagian kepalanya pada dinding sekum yang menyebabkan reaksi anafilaksis lokal yang dimediasi oleh imunoglobulin E (Ig E), terlihat infiltrasi lokal eosinofil di submukosa usus dan dapat terjadi edema pada dinding usus. Pada keadaan ini mukosa mudah berdarah. Pada infeksi berat dapat dijumpai mencret yang mengandung darah dan lendir (sindrom disentri), menimbulkan intoksikasi sistemik dan anemia. ${ }^{20}$ Trichuris trichiura disamping menggunakan karbohidrat juga akan menyebabkan anak kehilangan darah, seekor cacing dewasa menghisap $0,005 \mathrm{ml}$ darah per hari. ${ }^{3,14,20,21}$ Dari studi yang dilakukan pada tikus yang terinfeksi Trichuris trichiura muris, yaitu Nematoda yang berhubungan dekat dengan Trichuris trichiura pada manusia ditemukan juga adanya peran beberapa sitokin seperti interleukin (IL)-18, ${ }^{22}$ dan IL$10 .^{23}$ Interleukin 18 memegang peranan penting untuk terjadinya gangguan saluran cerna yang kronik sedangkan interleukin 10 berperan dalam pemeliharaan fungsi pertahanan kolon (colon barrier), sehingga bila terjadi defisiensi IL 10, fungsi penghalang (barrier) kolon akan terganggu dan dapat terjadi diare kronik (sindrom disentri trikuris).

Efek infeksi Trichuris trichiura dapat menyebabkan menurunnya insulin like growth faktor (IGF-1) suatu hormon pertumbuhan bersifat anabolik yang berfungsi pada pertumbuhan skeletal dan hematopoesis. Plasma IGF-1 meningkat pada masa anak dan mencapai puncaknya pada pubertas. Hormon ini merupakan marker biokimia yang baik untuk menilai gangguan pertumbuhan dan menilai gangguan nutrisi pada seorang anak. ${ }^{24}$ Dari suatu penelitian terhadap 14 anak usia sekolah dasar dengan sindrom disentri trikuris, didapatkan kadar plasma insulin like growth factor (IGF)-1 rendah, kadar serum tumor necrosis factor a (TNF) meningkat, serum albumin normal, konsentrasi rerata hemoglobin rendah, sintesis kolagen menurun. ${ }^{25}$

Secara keseluruhan infeksi Trichuris trichiura dapat menyebabkan diare kronik berat, serta hilangnya darah dalam jumlah besar, pernah dilaporkan kadar hemoglobin mencapai $3 \mathrm{gr} / \mathrm{dl}$ pada seorang pasien, ${ }^{20}$ menyebabkan plasma IGF-1 menurun, kadar TNF a meningkat dan sintesis kolagen menurun. ${ }^{25}$ Disamping itu umur Trichuris trichiura relatif panjang (10 tahun), ${ }^{3,14}$ semua keadaan ini secara tidak langsung akan mengakibatkan gangguan pertumbuhan pada anak.

\section{Pengaruh infeksi cacing tambang}

Infeksi cacing tambang pada manusia disebabkan oleh Necator americanus dan Ancylostoma duodenale. ${ }^{25,26}$ Manusia merupakan tuan rumah utama infeksi cacing tambang. Cacing dewasa hidup di sepertiga bagian atas usus halus, melekat pada mukosa usus, ${ }^{13}$ dan dapat bertahan selama 7 tahun atau lebih. ${ }^{3,12}$ Cacing tambang menghisap lebih banyak darah bila dibandingkan dengan Trichuris trichiura. Seekor Ancylostoma duodenale menghisap 0,16-0,34 $\mathrm{ml}$ darah per hari, sedangkan seekor Necator americanus menghisap 0.03 - 0,05 ml darah per hari. ${ }^{3,26,27}$ Luka yang diakibatkan gigitan Ancylostoma duodenale lebih berat dibandingkan kerusakan yang diakibatkan Necator americanus, selain itu diduga Ancylostoma duodenale memproduksi zat antikoagulan yang lebih kuat dibanding Necator americanus. Cacing ini menyebabkan laserasi pada kapiler villi usus halus dan menyebabkan perdarahan lokal pada usus. Sebagian dari darah akan ditelan oleh cacing dan sebagian keluar bersama dengan tinja. Pada infeksi sedang (angka telur pergram tinja lebih dari 5000) kehilangan darah dapat dideteksi dalam tinja rata rata $8 \mathrm{ml}$ per hari, sehingga menimbulkan gejala anemia dan defisiensi besi. ${ }^{22}$ Gejala klinis yang terjadi tergantung pada derajat infeksi, makin berat infeksi manifestasi klinis yang terjadi semakin mencolok, berupa, anoreksia, mual, muntah, diare, kelelahan, sakit kepala, sesak napas, palpitasi, dispepsia, nyeri disekitar duodenum, jejenum dan ileum. Juga bisa ditemukan ditemukan protein plasma yang rendah (bypoalbuminemia), kelainan absorpsi nitrogen dan vitamin B12, tetapi yang tetap paling menonjol adalah berkurangnya zat besi. ${ }^{2,26,27}$ Besi dalam tubuh manusia diperlukan untuk pembelahan sel, berperan dalam proses respirasi sel, yaitu sebagai kofaktor bagi enzim yang terlibat dalam reaksi oksidasi reduksi. Di dalam tiap sel, besi bekerjasama dengan rantai protein pengangkut elektron, yang berperan dalam langkah akhir metabolisme energi. Besi juga berperan dalam sistem kekebalan tubuh, kekurangan besi akan menyebabkan sel darah putih tidak dapat bekerja secara efektif dan berkurangnya pembentukan limfosit $\mathrm{T}$. Diduga penurunan pembentukan sel limfosit ini terjadi karena berkurangnya sintesis DNA akibat gangguan pada enzim reduktase ribonukleotida. Enzim ini membutuhkan zat besi untuk dapat berfungsi. ${ }^{13}$ Sehingga akibat infeksi kronik Cacing tambang akan dapat menyebabkan gangguan pembentukan sel dan 
kekebalan tubuh, gangguan penyembuhan luka. Keadaan ini secara tidak langsung akan mempengaruhi pertumbuhan anak.

Dari uraian di atas dapat diketahui pengaruh infeksi cacing usus terhadap pemasukan, pencernaan, penyerapan, serta metabolisme makanan. Infeksi cacing yang ditularkan melalui tanah termasuk penyakit yang berjalan kronis. Dapat berakibat hilangnya protein, karbohidrat, lemak, vitamin dan darah dalam jumlah yang besar, disamping itu dapat menimbulkan berbagai gejala penyakit seperti, diare, sindroma disentri dan defisiensi besi. Adanya cacing yang hidup pada usus anak secara terus menerus dapat menyebabkan aktifasi kronik respon imun dan ketidak seimbangan status imun. Borkow dkk, ${ }^{28}$ mendapatkan hasil, aktivasi kronik imun ini menyebabkan hyperesponsiveness dan anergi, menyebabkan penderita gampang terserang penyakit infeksi, dan secara tidak langsung menganggu tingkat pertumbuhan dan perkembangan anak. Karena itu mudah dimengerti pengaruh infeksi cacing usus terhadap gangguan pertumbuhan fisik anak. Namun dari berbagai literatur dan hasil berbagai penelitian masih banyak perbedaan pendapat mengenai pengaruh infeksi cacing usus terhadap pertumbuhan. Pada satu literatur disebutkan akibat infeksi Ascaris lumbricoides terhadap status gizi lebih dipengaruhi status ekonomi dan latar belakang nutrisi daripada pengaruh infeksi cacing ini secara langsung. ${ }^{14}$ Lai Karen PF. dkk, ${ }^{29}$ pada penelitiannya mendapatkan Ascaris lumbricoides dan Trichuris trichiura tidak memberikan kontribusi terhadap gangguan pertumbuhan pada anak usia sekolah dasar. Dari penelitian tersebut diketahui tidak ada perbedaan bermakna terhadap parameter pertumbuhan setelah diikuti selama dua tahun. Mereka berasumsi efek infeksi cacing usus terhadap pertumbuhan lebih dipengaruhi infeksi cacing tambang. Sehingga mereka merekomendasikan pada program yang ditujukan untuk memperbaiki status gizi anak, harus lebih dikonsentrasikan pada pemberian nutrisi yang adekuat, bukan hanya pengobatan infeksi cacing. Dari satu metaanalisis disimpulkan pengobatan rutin terhadap infeksi cacing usus pada anak usia sekolah dasar secara umum memberi efek pada perbaikan berat badan, tapi hasilnya tidak konsisten pada tiap penelitian dan hanya didapatkan sedikit fakta yang mendukung bahwa penggunaan antelmintik secara rutin dapat memperbaiki pertumbuhan dan performa kognitif pada anak di negara negara berkembang. ${ }^{30}$ Penelitian lain mendapatkan, infeksi cacing usus, dapat mengakibatkan gangguan pertumbuhan. Anak yang menderita askariasis, biasanya kehilangan nafsu makan, masukan makanan akan berkurang, sehingga berakibat gangguan gizi pada penderita tersebut. ${ }^{2}$ Pasaribu $S,{ }^{19}$ pada penelitiannya terhadap murid sekolah dasar di daerah Kabupaten Karo Sumatera Utara, mendapatkan bahwa pemberian albendazole dosis tunggal tiap 3 bulan, 6 bulan dan 12 bulan menyebabkan perbaikan status gizi.

\section{Kesimpulan}

Infeksi cacing usus berpengaruh terhadap pemasukan, pencernaan, penyerapan, serta metabolisme makanan, yang dapat berakibat hilangnya protein, karbohidrat, lemak, vitamin dan darah dalam jumlah yang besar. Juga dapat menimbulkan ganguan respon imun, menurunnya plasma insulin like growth factor (IGF)1, kadar serum tumor necrosis factor a (TNF) meningkat, konsentrasi rerata hemoglobin rendah, sintesis kolagen menurun. Disamping itu, juga menimbulkan berbagai gejala penyakit seperti anemi, diare, sindroma disentri dan defisiensi besi. 3,14,26,26 Sehingga anak penderita infeksi cacing usus merupakan kelompok resiko tinggi untuk mengalami malnutrisi. Respon tubuh terhadap infeksi cacing usus sangat bervariasi sehingga menimbulkan berbagai jenis gejala klinis. Bila akibat infeksi yang terjadi berat, misalnya malnutrisi maka gangguan pertumbuhan akan terjadi namun bila akibat yang ditimbulkannya ringan tidak terjadi gangguan pertumbuhan.

\section{Daftar Pustaka}

1. Warren KS, Bundy DAP, Anderson RM. Helminths infection. Dalam: Jamison DT, Mosley HW, Measham AR, Bobadilla JL, Penyunting Disease control priorities in developing countries. Oxford University Press. 1982.h. 131-60.

2. Hadju V, Stephenson L, Mohammed HO, Bowman DD, Parker R.S. Improvement of growth, appetite, and physical activity in helminth infected schoolboys 6 months after single dose of Albendazole. Asia Pacific J Clin Nutr.1988;7:170-6

3. Oemijati S, Iswandi EA. Tatalaksana pengendalian kecacingan di Indonesia melalui usaha kesehatan sekolah 
dengan pendekatan kemitraan. Trust team dan pusdiklat WHO collaborating center for health for all leadership development dan Direktorat pemberantasan penyakit menular langsung dan Tim Pembina usaha kesehatan sekolah bekerja sama dengan Smithkline Beecham Pharmaceutical. Jakarta: Dirjen PPM dan PLP Depkes RI. 1996.

4. Iswandi E A. Deworming program as an entry point in human resources development with partnership approach in Indonesia. Disampaikan pada regional workshop parasitic infections: behavioral change through communiyy participation at faculty of Tropical Medicine, Mahidol University, Thailand 23 - 24 September 1996.

5. Depari AA. Epidemiologi soil transmitted helminthiases di Indonesia. Disampaikan pada simposium sehari peran serta masyarakat dalam usaha penanggulangan penyakit kecacingan. Medan, 26 November, 1994

6. Siregar M. Penelitian status gizi dan tumbuh kembang anak menderita infeksi cacing usus dengan atau tanpa pengobatan di Propinsi Sumatera Utara. Laporan penelitian. Medan: Kanwil Departemen Kesehatan RI Propinsi Sumatera Utara. 1997.

7. Stephenson LS, Latham MC, Kurz KM, Kinoti SN, Brigham H. Treatment with a single dose of Albendazole improves growth of Kenyan schoolchildren with Hookworm, Trichuris trichiura and Ascaris lumbricoides infections. Trans R Soc Treop Med Hyg 1986;h.78-87

8. Onggowaluyo S, Ismid IS. Gangguan fungsi kognitif akibat infeksi cacing yang ditularkan melalui tanah. Maj Kedokt Indon. 1998;48:198-203

9. Suyitno H, Narendra MB. Pertumbuhan fisik anak. Dalam: Narendra MB, Sularyo TS, Soetjiningsih, Suyitno H, Gde Ranuh IGN, penyunting. Tumbuh kembang anak dan remaja. Edisi pertama.Jakarta: CV Sagung Seto, 2002. h. 51-61.

10. Soetjiningsih. Tumbuh kembang anak. Dalam: Gde Ranuh IGN, penyunting. Tumbuh kembang anak. Jakarta: Penerbit buku kedokteran EGC, 1998. h. 1-32.

11. Needlman RD. Early school years. Dalam: Behrman RE, Kliegman RM, Jenson HB, Penyunting. Nelson textbook of pediatric. Edisi-16. Philadelphia: Saunders, 2000. h. 50-2.

12. Pudjiadi S. Ilmu gizi klinis pada anak. Edisi Pertama. Jakarta: Balai Penerbit FKUI.1990.h.93-119

13. Almatsier S. Prisip dasar ilmu gizi. Jakarta: PT. Gramedia Pustaka Utama, 2001.h. 296-308.

14. Kazura JW. Helminthic diseases. Dalam: Behrman RE, Kliegman RM, Jenson HB, penyunting. Nelson text- book of pediatric. Edisi-16. Philadelphia: Saunders, 2000. h. 991-1006.

15. Ganong WF, penyunting. Review of medical physiologi. Edisi-20.San Fransisco: Mc Graw Hill, 2001. h. 450-60.

16. Haburchak DR. Ascariasis.eMedicine 2001 June (cited 2001 June 20). Available from: URL: http//www.eMedicine Journallascariasistopic 172.Htm.

17. Lubis CP, Pasaribu S. Askariasis. Dalam: Soedarmo SSP, Garna H, Hadinegoro SRS, penyunting. Buku ajar ilmu kesehatan anak infeksi dan penyakit tropis. Edisi pertama. Jakarta: Balai penerbit FKUI, 2002. h. 407-12.

18. Bundy DAP, Desilva N. Intestinal nematodes that migrate through lungs (ascariasis). Dalam: Hunter's tropical medicine. Edisi ke 8 Philadelphia: Saunders Co; 2000. h. 726-30.

19. Pasaribu S. Penentuan optimal pengobatan massal askariasis dengan Albendazole pada anak Sekolah Dasar di desa Suka. Ringkasan Disertasi. Program Pasca Sarjana USU Medan.2004

20. Lubis CP, Pasaribu S. Trikuriasis. Dalam: Soedarmo SSP, Garna H, Hadinegoro SRS, penyunting. Buku ajar ilmu kesehatan anak infeksi dan penyakit tropis. Edisi pertama. Jakarta: Balai penerbit FKUI, 2002. h. 413-7

21. Strickland GT. Trichuriasis. Dalam: Hunter's tropical medicine. Edisi ke 8 Philadelphia: W.B. Saunders Company; 2000. h. 722-4.

22. Helmby H, Takeda K, Akira S, Grencis RK. Interleukin (IL)-18 promote the development of chronic gastrointestinal helminthes infection by down regulating IL-13. J Exp Med 2001;194:355-64.

23. Schopf LR, Hoffman KF, Cheever AW, Urban JF, Wynn TA. IL-10 is critical for host resistance and survival during gastrointestinal helminthes infection. J Immunol 2002; 168:2383-92.

24. Clayton PE, Gill MS. Normal growth and its endocrine control. Dalam: Brook CGD, Hindmarsh PC, penyunting. Clinical pediatric endocrinology. Edisi ke-4. London: Blakwell science, 2003.h. 95-115.

25. Duff EMW, Anderson NM, Cooper ES. Plasma insulin like growth factor-1, type 1 procollagen and serum tumor necrosis factor a in children recovering from trichuris dysentery syndrome. Pediatr 1999;103:e69.

26. Lubis CP, Pasaribu S. Ankilostomiasis. Dalam: Soedarmo SSP, Garna H, Hadinegoro SRS, penyunting. Buku ajar ilmu kesehatan anak infeksi dan penyakit tropis. Edisi pertama. Jakarta: Balai penerbit FKUI, 2002. h. 41822.

27. Gilman RH. Intestinal nematodes that migrate through skin and lung Dalam: Hunter's tropical medicine. Edisi 
Sari Pediatri, Vol. 8, No. 2, September 2006

ke 8 Philadelphia: W.B. Saunders Company; 2000. h. 730-6.

28. Borkow G, Leng Q, Weisman Z. Chronic immune activation associated with intestinal helminth infections result in impaired signal transduction and anergy. J Clin invest 2000; 106:h.1053-60.

29. Lai Karen PF., Kaur H, Mathias RG, Ow-yang C.K. Ascaris and trichuris trichiura do not contribute to growth retardation in primary school children. Southeast Asian J Trop Med Public Health 1995; 26:322-8.

30. Dickson R, Awasthi S, Williamsom P, Demellweek C, Garner P. Effects of treatment for intestinal helminth infection on growth and cognitive performance in children: systematic review of randomized trials. BMJ 2000, 320:1697-701. 